УДК 336.228.32

Желєзнова Д.С., магістрант Донецького національного університету ім. Василя Стуса

Юрчишена Л.В., к.е.н., доцент, доцент кафедри фінансів і банківської справи Донецького національного університету ім. Василя Стуса

\title{
МЕХАНІЗМ ОПТИМІЗАЦІЇ ПОДАТКОВОГО НАВАНТАЖЕННЯ В СИСТЕМІ КОРПОРАТИВНОГО ПОДАТКОВОГО МЕНЕДЖМЕНТУ
}

У статті досліджено вплив податкового навантаження на фінансовогосподарську діяльність суб'єктів господарювання. Виявлені та проаналізовані фактори макро- та мікроекономічного впливу на рівень податкового навантаження підприємств. Досліджено рівень податкового навантаження на економіку України та країн світу. Визначено рівень розвитку податкової системи та сприяння розвитку бізнесу в Україні за даними Світового банку. Розглянуто особливості розподілу податкового навантаження за деякими податками та зборами на підприємствах України. Взаємний вплив окремих податків та зборів наведено через формулу податкового навантаження на підприємстві. Зазначені методи податкової оптимізації на підприємстві, включаючи складання податкового бюджету. Обгрунтована необхідність оптимізації податкових витрат на мікрорівні через створення механізму оптимізації податкового навантаження в системі корпоративного податкового менеджменту. Зазначені напрямки подальших досліджень у сфері управління податковими потоками підприємств.

Ключові слова: податки, податкове навантаження, корпоративний податковий менеджмент, оптимізація податкових витрат, механізм оптимізації податкового навантаження.

Рис.6, Табл.1, Літ.12.

Железнова Д.С., Юрчишена Л.В.

\section{МЕХАНИЗМ ОПТИМИЗАЦИИ НАЛОГОВОЙ НАГРУЗКИ В СИСТЕМЕ КОРПОРАТИВНОГО НАЛОГОВОГО МЕНЕДЖМЕНТА}

В статье исследовано влияние налоговой нагрузки на финансово-хозяйственную деятельность субъектов хозяйствования. Выявлены и проанализированы факторы макро- и микроэкономического влияния на уровень налоговой нагрузки предприятий. Исследован уровень налоговой нагрузки на экономику Украины и стран мира. Определен уровень развития налоговой системы и содействия развитию бизнеса в Украине по данным Всемирного банка. Рассмотрены особенности распределения налоговой нагрузки по некоторым налогам и сборам на предприятиях Украины. Взаимное влияние отдельных налогов и сборов приведены через формулу налоговой нагрузки на предприятии. Указанные методы налоговой оптимизации на предприятии, включая составление налогового бюджета. Обоснована необходимость оптимизации налоговых расходов на микроуровне через создание механизма оптимизации налоговой нагрузки в системе корпоративного налогового менеджмента. Указанные направления дальнейших исследований в области управления налоговыми потоками предприятий.

Ключевые слова: налоги, налоговая нагрузка, корпоративный налоговый менеджмент, оптимизация налоговых расходов, механизм оптимизации налоговой нагрузки. 


\section{Zhelieznova D., Yurchyshena L. \\ TAX BURDEN OPTIMIZATION MECHANISM IN CORPORATE TAX MANAGEMENT}

The article examines the impact of the tax burden on the financial and economic activities of business entities. Identified and analyzed factors of macro and microeconomic impact on the level of tax burden of enterprises. The level of tax burden on the economy of Ukraine and countries of the world has been studied. The level of development of the tax system and the promotion of business development in Ukraine has been determined according to the World Bank. The features of the distribution of the tax burden for some taxes and fees at the enterprises of Ukraine are considered. The mutual influence of individual taxes and fees are given through the formula of the tax burden on the enterprise. These methods of tax optimization in the enterprise, including the preparation of the tax budget. The necessity of optimizing tax expenses at the micro level through the creation of a mechanism to optimize the tax burden in the system of corporate tax management is substantiated. These areas for further research in the management of tax flows of enterprises.

Key words: taxes, tax burden, corporate tax management, tax expense optimization, tax burden optimization mechanism.

Постановка проблеми. Управління податковими потоками є важливою ланкою фінансово-господарської діяльності підприємства. Від грамотних професійно прийнятих рішень у сфері оподаткування залежить подальший розвиток та можливості зростання підприємства. Оптимізація податкового навантаження дає змогу вибрати найвигідніший варіант оподаткування діяльності підприємства в рамках чинного законодавства. Недооцінка цієї сторони фінансового процесу, допущені помилки при оподаткуванні господарських операцій можуть обернутися для підприємства значними фінансовими втратами.

Реальні умови господарювання в Україні характеризуються надмірним рівнем податкового навантаження на бізнес та нестабільністю податкового законодавства, що стримує розвиток підприємницької діяльності суб'єктів господарювання. Тому одним із визначальних чинників зростання бізнесу $\epsilon$ створення ефективного та гнучкого механізму оптимізації податкового навантаження на підприємстві, що виступає головною метою корпоративного податкового менеджменту.

Аналіз останніх досліджень і публікацій. Дослідженням питання сутності податкового навантаження та впливу на економічну активність суб'єктів господарювання розглядали такі вчені як О.В. Годованець, Ю.М. Кушнірчук, П.Т. Колісніченко, Н. Ткачук, Н.Ф. Стеблюк, А.О. Філін, О.М. Тищенко та інші. Динаміку рівня податкового навантаження на макро- та мікрорівнях досліджували такі вчені як Т.В. Пономарьова, В.М. Кміть, Л.І. Новосельська, О.М. Антіпов, В.Я. Оліховський та інші. Проте питання щодо оптимізації податкового навантаження на підприємстві залишається відкритим та потребує подальших досліджень.

Визначення невирішених питань в обраній для дослідження проблемі. Сьогодні залишається відкритою проблема щодо розробки механізму оптимізації податкового навантаження в системі корпоративного податкового менеджменту. Відсутні послідовність дій щодо виявлення, контролю та розробки варіантів оптимізації надмірного податкового навантаження на підприємстві.

Метою статті $\epsilon$ виявлення основних факторів, що впливають на рівень оподаткування підприємств та формування механізму оптимізації податкового 
навантаження в системі корпоративного податкового менеджменту, що сприяє вивільненню додаткових фінансових ресурсів для стабільного розвитку підприємств.

Виклад основного матеріалу. Податкове навантаження на корпоративному рівні визначає частку доходу, яка безповоротно вилучається державою у суб'єкта підприємництва через систему податків та зборів до бюджетів різних рівнів. Коли підприємство сплачує на користь держави надмірні суми коштів, тобто податкове навантаження на бізнес збільшується, податковий менеджмент підприємства повинен загострити увагу на цій проблемі та на основі створеної системи стягнення податків запропонувати механізм оптимізації податкового навантаження на підприємстві.

При розробці механізму оптимізації податків розглядаються фактори макро- та мікроекономічного впливу на рівень оподаткування підприємств. Такі фактори вказують на першочерговість впливу податкової оптимізації при плануванні. Макроекономічні фактори розглядаються як такі, що не можуть коригуватися, але чинять значний вплив на діяльність підприємства. До них відносять економічну ситуацію в країні, рівень податкового навантаження на економіку, принципи державної податкової політики та нормативно-правове поле [1, с.123].

Сьогодні у більшості країн світу рівень податкового навантаження розраховується як відношення суми сплачених податків, включаючи відрахування на обов'язкове соціальне страхування, до валового внутрішнього продукту. ЄСВ належить до неподаткових платежів, але включається до цього розрахунку, бо чинить значний фіскальний тиск на фонд оплати праці та $\epsilon$ вагомим чинником розвитку підприємництва.

Так, 32012 по 2017 роки загальний рівень податкового навантаження на економіку України змінювався з 35,9\% до 33,1\% ВВП відповідно, тобто третина коштів суб'єктів господарювання та населення відчужувалася на користь держави (рис.1).

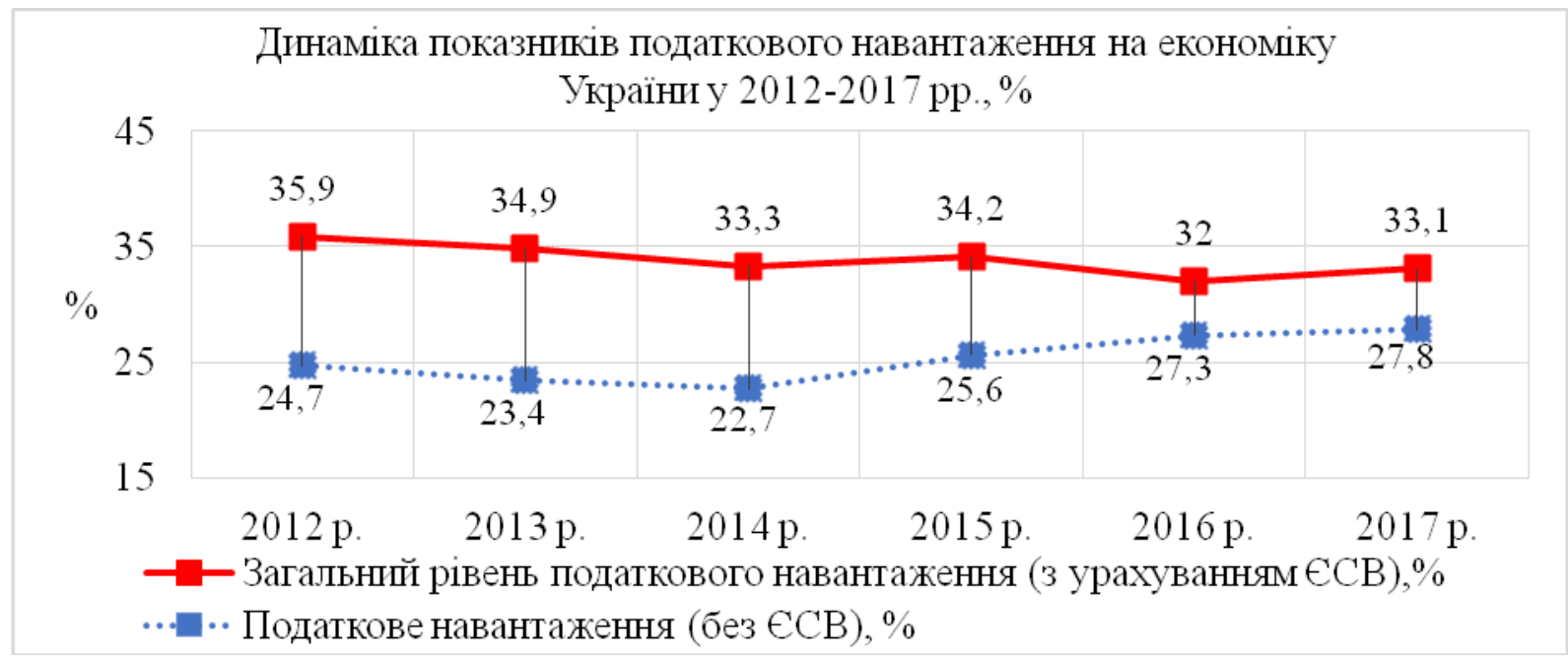

Примітка: побудовано автором на основі джерел [2-4]

Рисунок 1 - Динаміка показників податкового навантаження на економіку України у 2012-2017 pp.

Порівняно з розвиненими країнами світу рівень податкового тягаря української економіки є достатньо високим - 32\% ВВП. У країнах Свропи він становить близько $40 \%$ ВВП та розподіляється вкрай нерівномірно: суттєве податкове навантаження $51,6 \%$ у Ісландії та 47,6\% у Франції, у Данії - 47,3\%, Швеції - 44,6\%. А найнижчий податковий тиск в Румунії (26\%), США (26\%) та Ірландії (23\%). Рівень податкового 
тягаря в Норвегії та Німеччині становить приблизно 38\% ВВП, у Великобританії та Польщі близько $35 \%$ (рис. 2) [5].

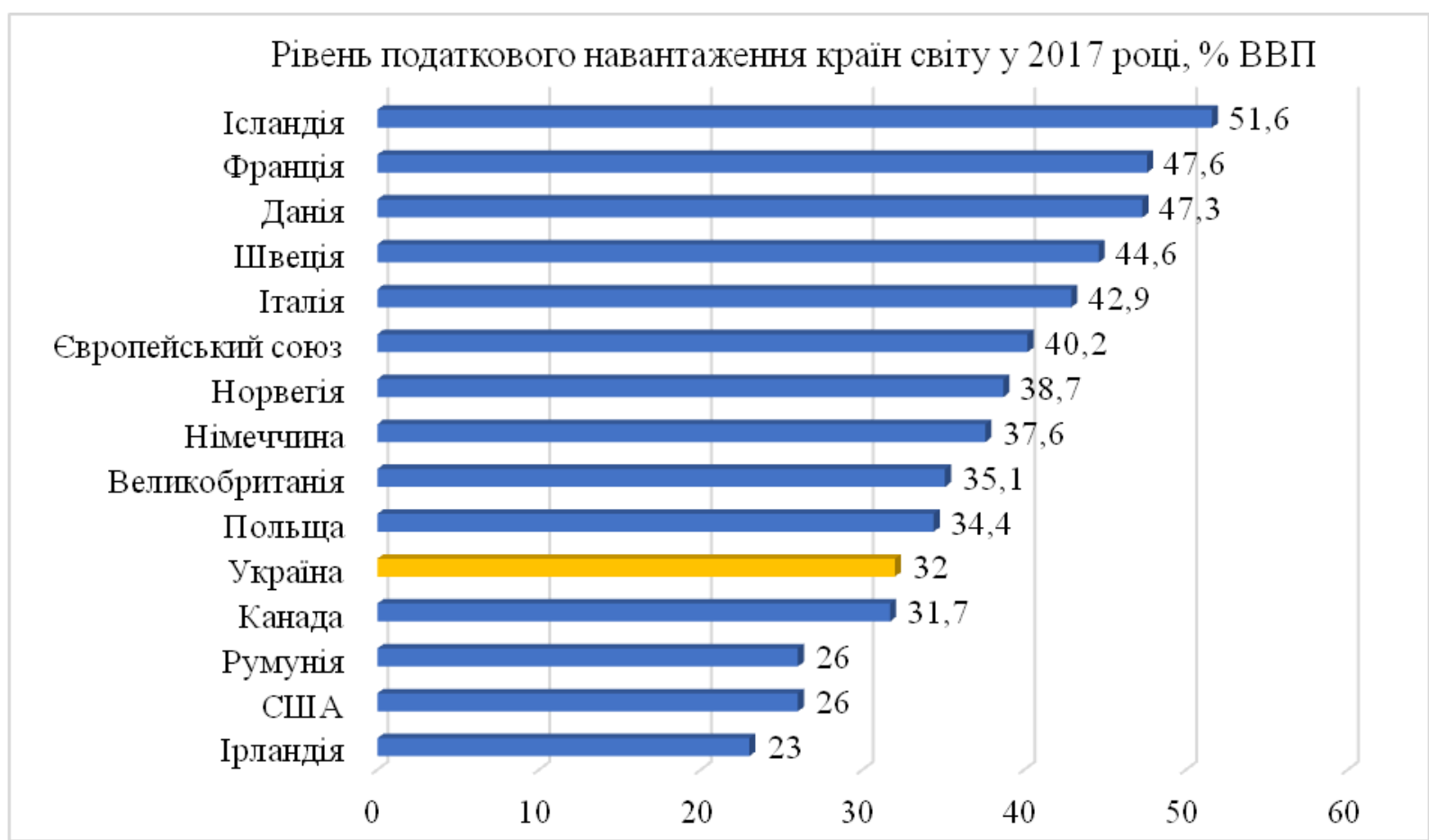

Примітка: побудовано автором на основі джерел [5]

Рисунок 2 - Рівень податкового навантаження в деяких країнах світу у 2017 році

При порівнянні податкового навантаження в різних країнах світу важливо врахувати ту частку податків, яка повертається населенню при перерозподілі доходів бюджету. Так, наприклад, для скандинавських країн така частка перерозподілених доходів становить близько 85\%, тоді як в Україні вона не перевищує 30\%.

Також американські економісти зазначають, що граничною ставкою вилучення до бюджету є ставка 30\% суми доходу, а 40-50\% вилучень доходів скорочує власні кошти підприємства, сприяє незацікавленості в інвестуванні й збільшує ризик скорочення податкових надходжень до бюджету через переходу підприємств до «тіні» [6, c.84].

Кожна країна світу намагається максимально наблизитися до оптимальних критеріїв фіскального тиску, які дозволяють взаємодіяти державним органам влади та підприємствам із врахуванням інтересів кожної зі сторін. Підтвердженням достатньої ефективності системи оподаткування в Україні є покращення позицій в міжнародних рейтингах. Основним показником ефективності податкової системи у світі вважається визначений міжнародним рейтингом Doing Business, що складається Світовим банком, індикатор «Сплата податків», який складається з трьох показників:

1) кількість платежів протягом року;

2) витрати часу на підготовку податкової звітності і сплату податків для трьох основних податків (ПДВ, податок на прибуток, ССВ);

3) узагальнена ставка податку.

Динаміка таких показників та рівень розвитку податкової системи України наведені у таблиці 1. 3 даних таблиці видно, що Україна до 2015 року займала одні 3 останніх позицій у списку країн за рівнем розвитку податкової системи. Але після проведення реформ у податковій сфері, зокрема, скорочення кількості податкових 
платежів, спрощення умов обчислення та сплати податків, удосконалення систем автоматизації адміністрування податків Україна піднялася у рейтингу на 43 місце, що говорить про сприяння привабливості розвитку бізнесу в країні [7].

Таблиця 1 - Динаміка показників, що характеризують рівень розвитку податкової системи України

\begin{tabular}{|c|c|c|c|c|}
\hline Рік & $\begin{array}{c}\text { Кількість } \\
\text { платежів } \\
\text { на рік }\end{array}$ & $\begin{array}{c}\text { Час до сплати } \\
\text { податкових платежів } \\
\text { на рік, час }\end{array}$ & $\begin{array}{c}\text { Сукупна } \\
\text { податкова ставка, } \\
\text { \% від прибутку }\end{array}$ & $\begin{array}{c}\text { Місце України серед інших } \\
\text { країн світу за рівнем } \\
\text { розвитку податкової системи }\end{array}$ \\
\hline 2009 & 99 & 848 & 58,4 & 180 місце серед 181 країни \\
\hline 2011 & 135 & 657 & 55,5 & 181 місце серед 183 країн \\
\hline 2013 & 28 & 491 & 55,4 & 165 місце серед 185 країни \\
\hline 2015 & 5 & 350 & 52,2 & 107 місце серед 189 країни \\
\hline 2017 & 5 & 327,5 & 37,8 & 43 місце серед 190 країн \\
\hline \multicolumn{4}{r|}{ Примітка: побудовано автором на основі джерела [7] }
\end{tabular}

Розробка механізму оптимізації податкового навантаження базується на вивчені мікроекономічних факторів. До таких факторів можна віднести вибір системи оподаткування (загальна або спрощена), місцезнаходження, масштаби та вид діяльності підприємства, структуру податкових витрат, рівень прибутковості, кількість працівників тощо.

На початку створення підприємства доцільно акцентувати увагу на виборі системи оподаткування. Згідно статті 291 ПКУ підприємство може обрати спрощену систему оподаткування, сплачуючи тільки єдиний податок та оптимізуючи податкові витрати [8]. Але дана система накладає ряд обмежень щодо доходу, видів діяльності та кількості найманих працівників, що унеможливлює іï використання для великих виробничих підприємств.

Вибір місцезнаходження при створенні підприємства дає змогу звільнитися або зменшити податкові зобов'язання шляхом реєстрації фірми у економічних зонах 3 пільговими режимами оподаткування. Масштаби та вид діяльності передбачають вибір особливостей здійснення господарської діяльності. Зокрема реєстрація підприємства як платника ПДВ дає змогу зменшити податкові зобов'язання $з$ даного податку, коли підприємство є виробником продукції та має витрати для нарахування податкового кредиту з ПДВ, а основа група контрагентів підприємства $є$ платниками ПДВ [8].

При розробці способів оптимізації податкових витрат доцільно акцентувати увагу на видах податків та зборів, які складають найбільшу питому вагу на підприємстві (у частині сум податків, що відчужуються на користь держави) (рис. 3). Найбільший вплив на діяльність підприємств у 2017 році надають ПДВ - 14,6\% ВВП, податок на прибуток - 2,5\% ВВП та внесок на соціальне страхування у розмірі 5,3\% ВВП. Варто відзначити, що до 2015 року частка ССВ була високою - більше $10 \%$ ВВП, що обумовлювалось високими податковими ставками - від $34,7 \%$ бази нарахування в залежності від класу професійного ризику. 32016 року ставка ЄСВ знизилась до $22 \%$ й відповідно рівень податкового тиску на підприємства значно скоротився.

Створений та діючий на підприємстві механізм стягнення податків повинен відповідати цілям податкової політики підприємства та основним цілям його функціонування. Якщо ефективність податкового менеджменту падає, то слід передивитися систему справляння податків та запровадити механізм оптимізації податкових витрат, розглядаючи у комплексі господарську та фінансову діяльність підприємства та керуючись основними методами податкової оптимізації. 
Розподіл податквого навантаження за деякими податкамп і зборами в Україні, \% ВВП

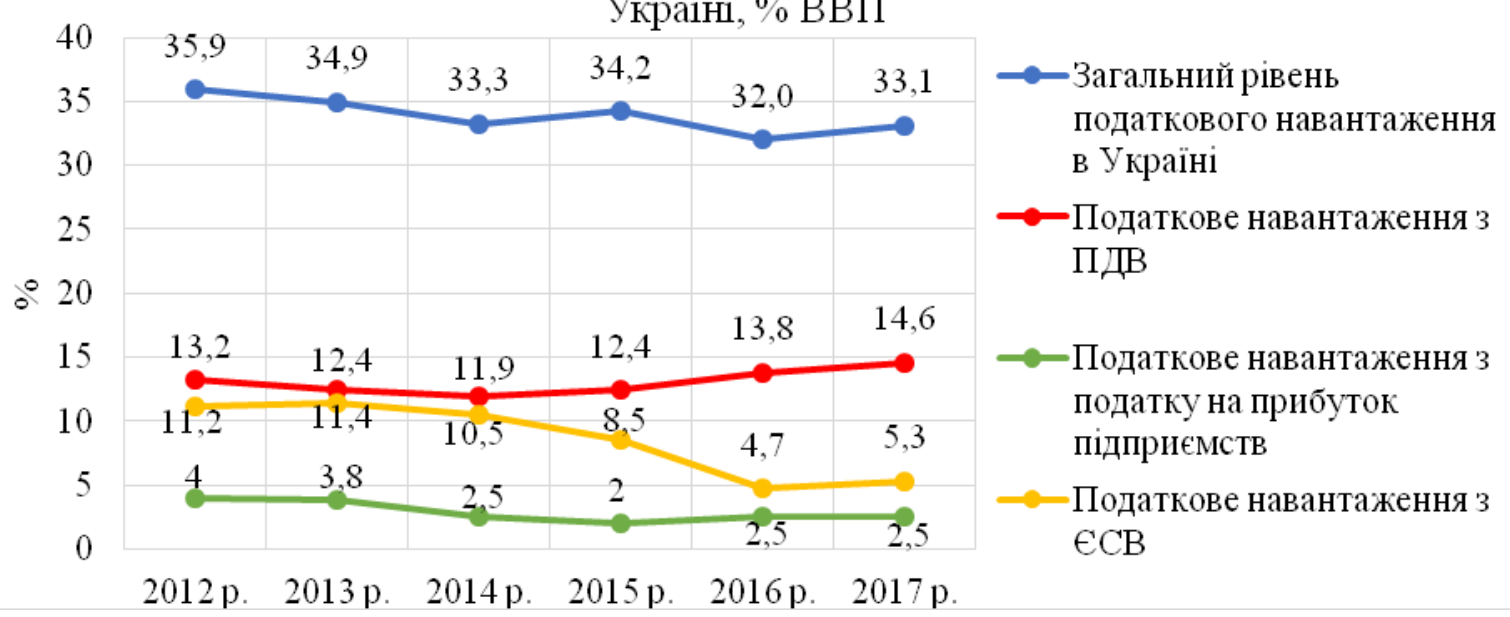

Рисунок 3 - Розподіл загального рівня податкового навантаження за деякими податками і зборами в Україні, у \% до ВВП

Примітка: розраховано автором на основі джерел [2-4]

Існують дві групи методів податкової оптимізації, які дозволять спрогнозувати, розрахувати податкові платежі за альтернативними варіантами здійснення господарської діяльності й вибрати оптимальний варіант оподаткування (рис. 4).

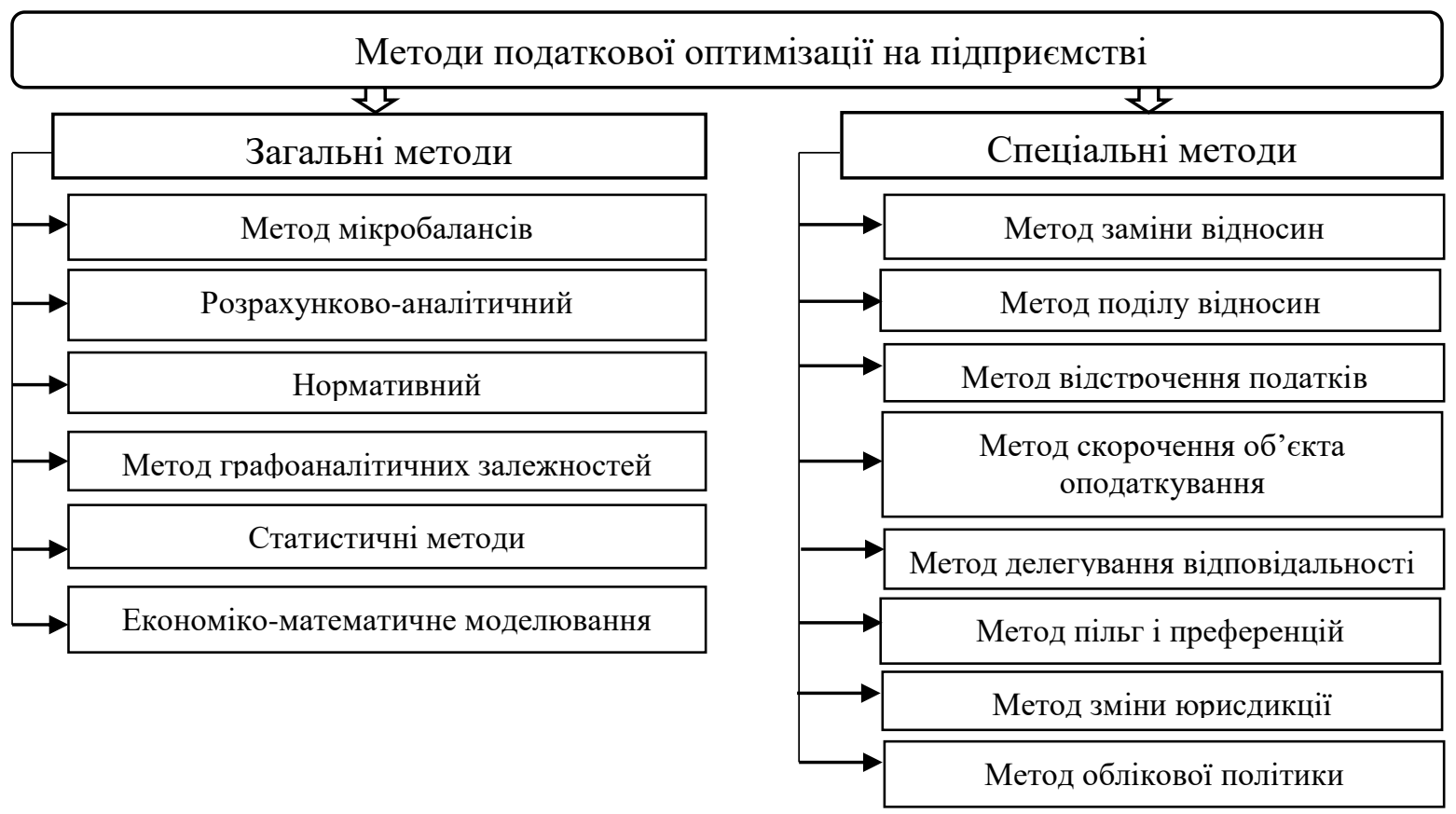

Рисунок 4 - Методи податкової оптимізації на підприємстві

Примітка: побудовано автором на основі джерел [9]

Методи податкової оптимізації поділяються на загальні та спеціальні і $є$ найбільш ефективними при їх поєднанні. Вони дають змогу підприємству досягти поставлених цілей (зростання продажів, прибутку тощо) в найбільш короткий проміжок часу з найменшими податковими витратами 3 урахуванням довготривалої перспективи економічного зростання і фінансової стабільності підприємства [9, с.338]. 
Виходячи 3 критерію податкової оптимізації на окремому підприємстві необхідно враховувати специфіку і механізм дії наступних обов'язкових платежів: податку на додану вартість, податку на прибуток підприємств, зборів до позабюджетних фондів України. У цілому податкове навантаження на підприємстві можна визначити у вигляді наступної формули (1) [10, с.225]:

$$
T=\frac{\left(Y-M-\left(1+t_{3}\right) * W-A-E\right) * t_{1}+(Y-M) * t_{2}+W * t_{3}}{V_{\alpha}} * 100 \%,
$$

де, $Y$ - вартість продукції, робіт, послуг (без ПДВ);

$M$ - витрачені матеріали і одержані послуги (без ПДВ);

$W$ - сума витрат на оплату праці працівників;

$A$ - сума амортизаційних відрахувань;

$E$ - суми інших операцій, що коректують базу податку на прибуток;

$t_{1}$ - ставка податку на прибуток підприємств;

$t_{2}$ - ставка податку на додану вартість;

$t_{3}$ - ставка єдиного внеску на загальнообов'язкове соціальне страхування;

$V_{a}$ - додана вартість.

У розглянутій формулі показник, 3 яким повинна співвідноситься сума податкових платежів підприємства до бюджету є додана вартість, оскільки вона $є$ джерелом їх сплати. Додана вартість представляє собою різницю між вартістю виробленої продукції і перенесеною вартістю матеріальних ресурсів, спожитих у процесі виробництва такої продукції [11, с.123]. Таке судження підтверджує й той факт, що для розрахунку податкового навантаження на економіку країни базою порівняння $\epsilon$ ВВП, тобто сума валової доданої вартості, створеної галузями економіки за рік.

Дана формула дає можливість проаналізувати взаємний вплив окремих платежів на загальне податкове навантаження і провести оцінку можливості застосування окремих методик податкової мінімізації:

1. Незалежний від інших чинників виробництва зростання об'ємів продажів приводить до збільшення податкових зобов'язань з ПДВ і податку на прибуток.

2. Незалежне зростання матеріальних витрат приводить до скорочення поточних податкових зобов'язань по ПДВ і податку на прибуток.

3. Збільшення суми амортизаційних відрахувань і валових витрат приводить до скорочення відрахувань тільки по податку на прибуток.

4. Збільшення витрат на оплату праці працівникам підприємства, змінює, окрім бази обкладення платежів обчислюваних від фонду оплати праці і заробітної платні, базу податку на прибуток. У певних умовах це може приводити до скорочення загального податкового навантаження.

Для побудови механізму податкової оптимізації підприємницької діяльності особливе значення має бюджетування, під час якого прогнозуються суми податкових платежів на плановий період. Податкове бюджетування є підсумковою частиною корпоративного податкового планування, регулювання та контролю, а також комбінованим способом оптимізації податкових потоків суб'єктом господарювання. Податкове бюджетування базується на виборі оптимальних рішень у сфері податкових доходів і витрат з метою отримання максимального податкового прибутку з подальшим ухваленням рішень щодо його ефективного використання [12, с. 221].

Результати корпоративного податкового бюджетування повинні відображатися в податковому бюджеті, який розробляється підприємством. У податковому бюджеті відображаються всі можливі податкові доходи і витрати підприємства, визначається 
загальний податковий результат управління податковими потоками і ухвалюються адекватні рішення щодо продовження заходів податкової оптимізації або про розгляду інших iï варіантів. Модель такого податкового бюджету та варіанти можливих управлінських рішень представлені на рисунку 5.

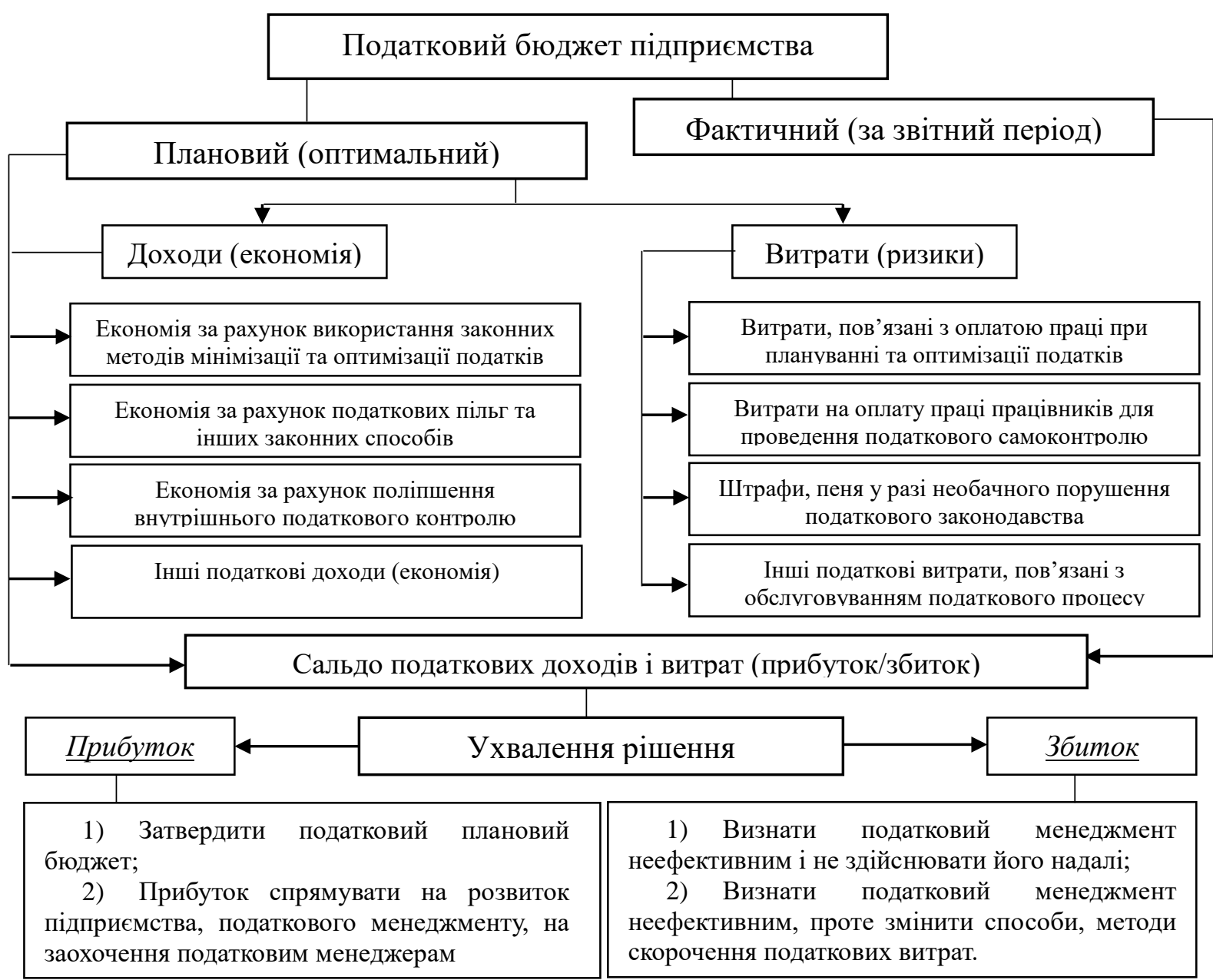

Рисунок 5 - Модель податкового бюджету підприємства

Примітка: побудовано автором на основі джерел [12]

Отже, податковий менеджмент підприємства, як складова фінансового менеджменту передбачає розробку управлінських рішень, спрямованих на формування фінансового потенціалу і підвищення його ефективності. Його основна мета не зводиться до абсолютної мінімізації податкових платежів, а полягає в активному впливі на максимізацію чистого прибутку підприємства при заданих параметрах податкового середовища і ринкової кон'юнктури.

Податкова оптимізація системно пов'язана 3 усіма процесами управління підприємством та грунтується на податковому плануванні, аналізі, обліку та контролю. Оптимізація податкового навантаження представляє собою механізм реалізації податкової політики в господарській практиці підприємства, починаючи від постановки мети до контролю ефективності реалізації обраного варіанта оподаткування (рис. 6).

Щодо мети податкової оптимізації, то спочатку формуються пріоритетні завдання податкового діяльності, враховуючи особливості функціонування підприємства. Після постановки мети здійснюється огляд законодавства та нормативно- 
правових актів з питань оподаткування та бухгалтерського обліку.

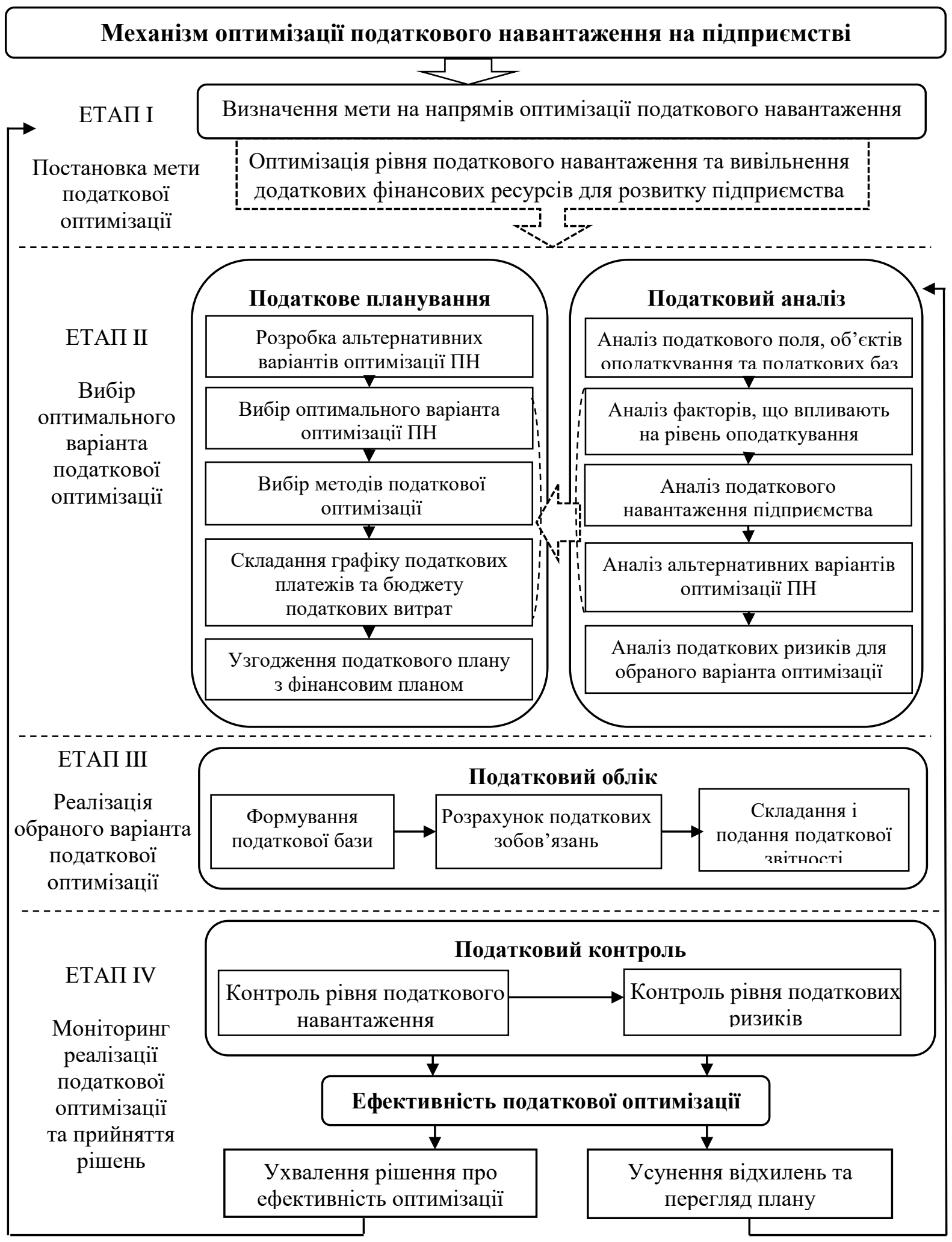

Рисунок 6 - Механізм оптимізації податкового навантаження в системі корпоративного податкового менеджменту 
Обов'язково оцінюється обсяг інформаційних та трудових ресурсів, технічного забезпечення та відповідність мети потребам підприємства.

На наступному етапі здійснюється вибір оптимального варіанта податкової діяльності підприємства. Для цього аналізується податкове поле суб'єкта господарювання, виявляються фактори впливу на податкове навантаження, вивчаються напрямки та методи оптимізації податкових баз, а також визначаються фактори, що формують структуру податкового навантаження.

На підставі результатів аналізу розробляються декілька альтернативних варіантів здійснення податкової діяльності. Далі оцінюється кожний варіант на підставі розрахунків рівня податкового навантаження та обирається найвигідніший варіант, що відповідає плану оптимізації.

Для обраного варіанту оптимізації обираються відповідні методи оптимізації, які можуть вплинути на формування податкової бази, структуру податкового навантаження. Далі проводяться розрахунки податкових платежів, складається податковий бюджет витрат та податковий календар на поточний період. На цій основі проводиться аналіз й оцінка податкових ризиків підприємства у разі реалізації обраного варіанта оптимізації.

Реалізація обраного варіанта податкової діяльності передбачає коригування податкових баз, ведення обліку операцій підприємства, складаються розрахунки податкових зобов'язань та подається податкова звітність відповідно до графіку сплати податкових платежів.

Моніторинг виконання плану оптимізації спрямований на здійснення контролю за рівнем податкового навантаження та рівнем податкових ризиків, поточному коригуванні показників. Контрольна функція стосується як податкової діяльності, так і господарських операцій підприємства.

Після цього наступає головний етап податкової оптимізації - прийняття рішень щодо успішної та ефективної реалізації механізму оптимізації податкового навантаження на підприємстві. Якщо після використаних методів та способів оптимізації податкове навантаження зменшиться, то оптимізація пройшла успішно і механізм варто впроваджувати у діяльність підприємства.

Висновки та перспективи подальших досліджень. Запровадження механізму оптимізації податкового навантаження на підприємстві $є$ головною умовою його стабільного розвитку. Використання методів оптимізації та вибір оптимального варіанту оподаткування дасть можливість підприємству сплачувати податкові платежі в необтяжливому для нього розмірі, направляти зекономлені кошти на подальший розвиток та зменшити податкові ризики. Такий елемент управління податковими потоками підприємства балансує відносини між фіскальними органами та суб'єктами господарювання, що надає, в свою чергу, державі забезпечення повного надходження податкових платежів до бюджету.

Напрямками подальших досліджень може стати використання запропонованого механізму оптимізації податкового навантаження у господарській практиці конкретного підприємства. На цій основі можливе прогнозування податкових витрат та податкового навантаження на конкретне підприємство, що дозволить зробити практичну оцінку та ефективність запровадження даного механізму на підприємствах України. 


\section{Література:}

1. Ткачук Н. Вплив податкового навантаження на діяльність суб'єктів господарювання в умовах реформування фінансової системи України. Економічний часопис Східноєвропейського національного університету імені Лесі Українки, 2015. № 4. С. 121-128.

2. Доходи Бюджету та Пенсійного фонду. Ціна держави. URL: http://cost.ua/budget/revenue/ (дата звернення: 16.09.2018).

3. ВВП України. Фінансовий портал Міністерства фінансів України. - URL: http://index.minfin.com.ua/index/gdp/ (дата звернення: 16.09.2018).

4. Статистична інформація. Державний служба статистики України. Офіційний сайт. URL: http://www.ukrstat.gov.ua (дата звернення: 16.09.2018).

5. Main national accounts tax aggregates. Eurostat. URL: https://ec.europa.eu/eurostat/data/database (дата звернення: 17.09.2018).

6. Стеблюк Н.Ф., Філін А.О. Вплив податкового навантаження на діяльність підприємств. Молодий вчений. Економічні науки, 2015. № 8. С. 80-86.

7. World bank group Paying taxes. URL: http://www.doingbusiness.org/ data/exploretopics/paying-taxes (дата звернення: 18.09.2018).

8. Податковий кодекс України від 02.12.2010 року № 2755-VI. URL: http://zakon4.rada.gov.ua/laws/show/2755-17 (дата звернення: 19.09.2018).

9. Атаманенко І.Б. Ефективність методів податкового планування. Вісник Національного університету «Львівська політехніка»: Серія «Логістика», 2010. Вип. 669. C. 335-341.

10. Ползікова Г.В. Методи та інструменти податкової оптимізації. Економічний простір, 2015. №93. С. 221-229.

11. Іваненко В.О. Додана вартість як об'єкт аналізу статистичної звітності промислових підприємств з виробництва продукції. Проблеми теорії та методології бух. обліку, контролю і аналізу, 2012. Вип.1 (22). С.122-130.

12. Бечко П.К., Лиса Н.В. Податковий менеджмент: навч. посіб. [для студ. вищ. навч. закл.]. Київ: Центр учбової літератури, 2009. 288 с. 